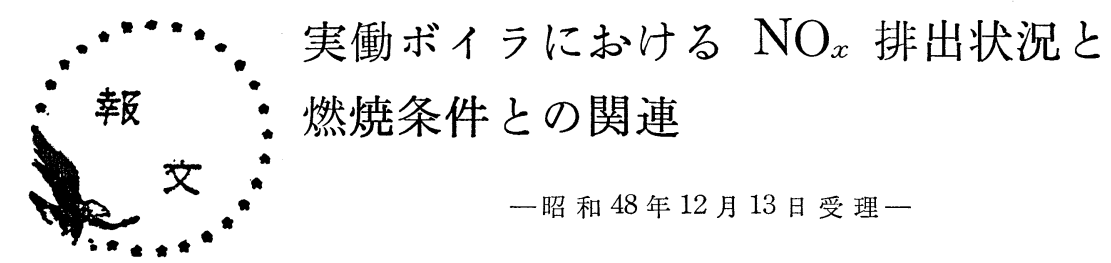

早稲田大学理工学部 永田勝也・本間裕士 広田幹雄・松原邦博

\section{1. まえがき}

現在, 深刻な社会問題になっている大気污染は, そ の原因物質のほとんどが燃焼によって発生していると いっても過言ではない。わが国ではこれまでに, 固定 燃焼装置から排出される大気污染物質として規制がと られているのは, 煤塺, い抢ら酸化物 $\left(\mathrm{SO}_{x}\right)$ および 窒素酸化物 $\left(\mathrm{NO}_{x}\right)$ である。このうち $\mathrm{NO}_{x}$ はごく最 近, 排出基準が決定されたものであり, 周知のように それ自身の有害性とともに光化学スモッグの原因物質 としてこの数年, 各界からとみに関心が寄せられてい る污染物質である。

$\mathrm{NO}_{x}$ に関しては，その排出量も多いことから自動 車用機関, 特にガソリンエンジンについては, かなり 以前より排出状況の調查と低減方策の検討がなされて おり,わが国においても, 米国のマスキ一法なみの積 極的な低減化のタイムスケジュールが打ち出されてい る。一方, ふりかえって定置燃焼装置を見ると, わが 国はもちろん米国においてすら電力用の大形ボイラ以 外の施設からの排出量の調査は充分とはいい難く, 低 減法についての研究も自動車に一歩遅れをとっている といわざるをえない。

燃燒による $\mathrm{NO}_{x}$ の発生は, 燃焼中のいおう分によ りその排出量の推定が可能な $\mathrm{SO}_{x}$ とは異なり, 燃料 の種類および性状, 燃焼の方法, 燃焼室の構造などに よりかなり大幅に変化する。このことが定置燃燒装置 からの排出状況の把握を難しいものにしている。

筆者らは数年前より, 定置燃焼装置からの $\mathrm{NO}_{x}$ の 発生と抑制法について研究を行なってきたが, ここで は最大の固定排出源と考えられるボイラからの $\mathrm{NO}_{x}$ 排出状況のこれまでの調查結果と燃焼条件との関連性 について報告することにする1)。

\section{2. 測定対象ボイラ}

$\mathrm{NO}_{x}$ の計測を行なったボイラは，暖冷房用あるい は工場用の蒸気源として使用されている, 中, 小形の
ものである。Table 1 にその諸元を示す。

$\mathrm{A}$ から F までは水管式， $\mathrm{G}$ およびH炉筒煙管式， そしてI は小形貫流ボイラである。このらちボイラ I は試験用として, 他の実働ボイラの結果の考察を行な らために用いている。ボイラAおよびBは同形式のも のであり, 製造年も非常に近い。またボイラB B都市 ガスか灯油のいずれか一方の専焼を行なら方式になっ ている。ボイラC も同形式のものであるが， A， B と は違って然焼用空気の予熱を行なっており, 製造もか なり古い。ボイラ $\mathrm{E} は$ 蒸気タービンテスト用のため, 蒸気圧, 蒸気温度ともかなり高く, 給水ならびに燃焼 用空気の予熱を行なっている。

燃料としては, 前述のボイラBが都市ガスと灯油を, また I が灯油を用いている以外はいずれのボイラも， Table 2 に示すように重油を使用している。なお Table 2 中のN分含有率は後揭の Fig. 22 より推定した值で ある。

$\mathrm{NO}_{x}$ などの計測は, 通常の使用状態で自動運転を 行なっている場合を主に行ない，可能なものについて は, 運転に支障のない範囲で燃焼量一定, 空気比変化 の定常運転状態でも測定を行なった。Table 2 には, ○印で各ボイラについての計測状況を示した。

\section{3. 測定の方法}

$\mathrm{NO}_{x}$ 濃度の測定では, $\mathrm{NO}_{x}$ メータによる連続分析 と併行して，JIS・K 0104 に準拠したナフチルエチ レンジアミン法 (ザルツマン法) による化学分析も行 なった。

連続分析の $\mathrm{NO}_{x}$ メータは, $\mathrm{NO}$ と $\mathrm{NO}_{2}$ の酸化還 元電位を検出して濃度を知るという測定原理によるも のであって, $\mathrm{NO}_{x}$ 以外の燃焼ガス成分の影響は非常 に少ないとされている。ただし，このメータでは NO と $\mathrm{NO}_{2}$ の分離測定はできない。これに対してザルッ マン法では, $\mathrm{NO}+\mathrm{NO}_{2}$ についてはアンモニア水, $\mathrm{NO}_{2}$ に対しては水酸化ナトリウム溶液を吸收液とす 

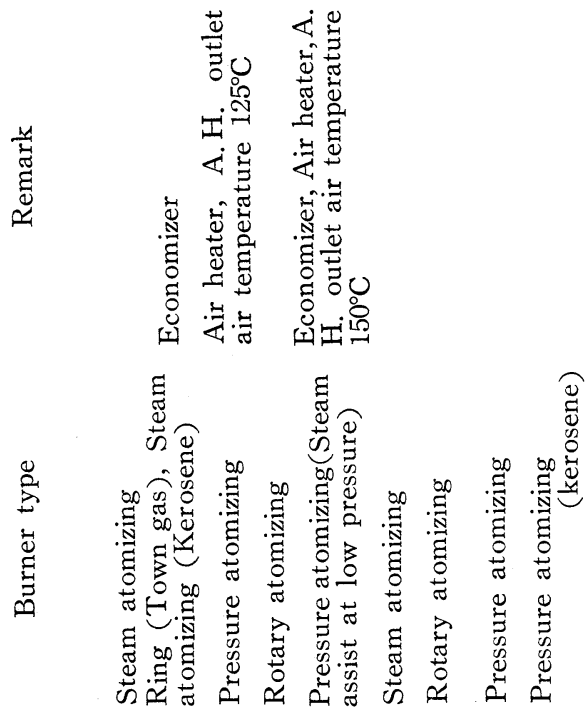

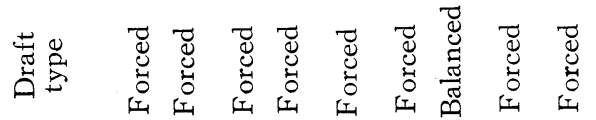

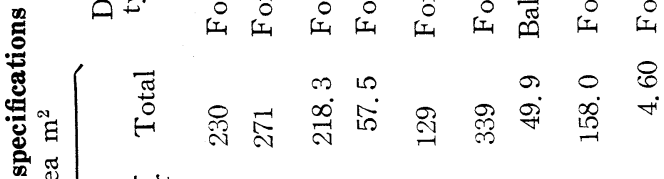

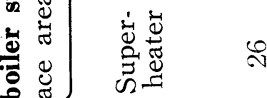

焉焉

它

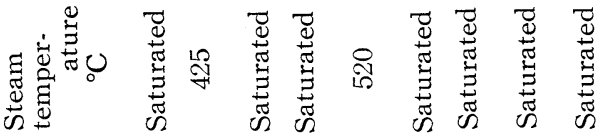

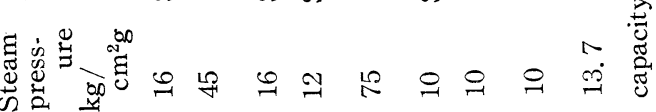

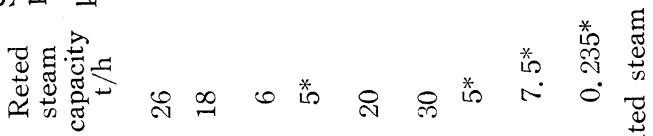

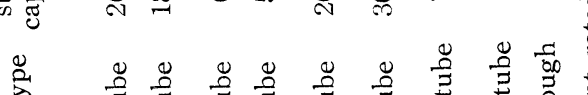

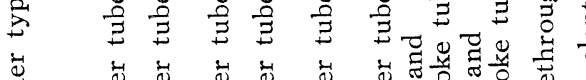

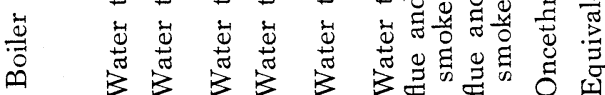

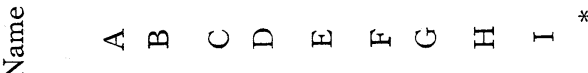

Table 2 Fuel and run condition

\begin{tabular}{|c|c|c|c|c|c|}
\hline \multirow[b]{2}{*}{ Name } & \multicolumn{3}{|c|}{ Fuel } & \multicolumn{2}{|c|}{$\begin{array}{l}\text { Run } \\
\text { condition }\end{array}$} \\
\hline & type & $\begin{array}{c}S \text { con- } \\
\text { tent } \\
\%\end{array}$ & $\begin{array}{l}\text { Estimu- } \\
\text { tal } N \text { co- } \\
\text { ntent \% }\end{array}$ & $\begin{array}{l}\text { Nor- } \\
\text { mal } \\
\text { state }\end{array}$ & $\begin{array}{l}\text { Con- } \\
\text { stant } \\
\text { road }\end{array}$ \\
\hline A & Heary fuel oil & 0.09 & 0.080 & 0 & \\
\hline$R$ & Town gas & 0.00 & 0.000 & 0 & 0 \\
\hline D & Kerosene & 0.00 & Negligible & 0 & 0 \\
\hline $\mathrm{C}$ & Heary fuel oil & 0.87 & 0.080 & 0 & \\
\hline $\mathrm{D}$ & Heary fuel oil & 1. 13 & 0.156 & 0 & \\
\hline $\mathrm{E}$ & Heary fuel oil & 0.68 & 0.020 & 0 & \\
\hline F & Heary fuel oil & 1.32 & 0.214 & 0 & \\
\hline $\mathrm{G}$ & Heary fuel oil & 0.09 & 0.080 & & \\
\hline $\mathrm{H}$ & Heary fuel oil & 0.81 & 0.060 & 0 & \\
\hline I & Kerosene & 0.00 & Negligible & & 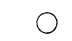 \\
\hline
\end{tabular}

ることによって， $\mathrm{NO}$ および $\mathrm{NO}_{2}$ の定量分析が可能 であるが，分析に要する時間は $\mathrm{NO}$ を酸化する必要 があるためかなり長くなる。（本測定では，NO の酸 化には今般改訂された JIS に示される通り純酸素を 用いている。)

Table 3 は $\mathrm{NO}_{x}$ メータとザルッマン法による測定 值の比較を示したものである。ザルツマン法では 1 条 件につき $3 \sim 5$ 回の測定を行なっており, 表中にはそ の平均值が示してある。ザルッマン法による場合の方 が $\mathrm{NO}_{x}$ メータより若干高い濃度を与えるが， $10 \mathrm{ppm}$ （絶対誤差 $8 \%$ ）以上の誤差はない。今回の計測は, 燃焼状態の変動がかなり激しい通常運転時が主なの で, 測定值としては $\mathrm{NO}_{x}$ メータによる連続分析結果 を採用している。ただし，ボイラ I の測定結果だけは ザルッマン法によるものである。

$\mathrm{NO}_{x}$ 発生に影響を及ぼす燃焼条件として空気比は 非常に重要な因子である。本測定においては，燃焼排 ガス中の $\mathrm{O}_{2}$ 濃度より空気比の算定を行なっている。

Table 3 Comparison of measurement values by NEDA method and $\mathrm{NO}_{x}$ meter

NEDA method $\mathrm{NO}_{x}$

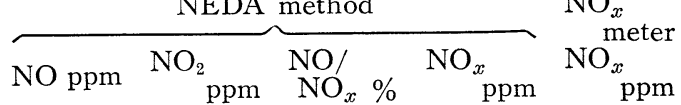

$\begin{array}{rrrrr}77 & 14 & 84.6 & 91 & 90 \\ 71 & 22 & 76.3 & 93 & 88 \\ 84 & 20 & 80.8 & 104 & 96 \\ 86 & 15 & 85.1 & 101 & 95 \\ 72 & 12 & 85.7 & 84 & 83 \\ 77 & 15 & 83.7 & 92 & 87\end{array}$


使用した $\mathrm{O}_{2}$ メータは前述の $\mathrm{NO}_{x}$ メータと類似の測 定原理をもつものである。測定に際しては, オルザー トガス分析器によって検量を行なったが，かなり良い 一致が得られた。

Fig. 1 は計測時の $\mathrm{NO}_{x}$ メータと $\mathrm{O}_{2}$ メータの接続 要領を示したものである。 $\mathrm{NO}_{x}$ および $\mathrm{O}_{2}$ 濃度の測 定はいずれの場合も煙道に設けられている測定孔で行 なったが，測定点での濃度分布はほとんどなく，煙道 の中央点付近における計測結果を代表值として採用し ている。

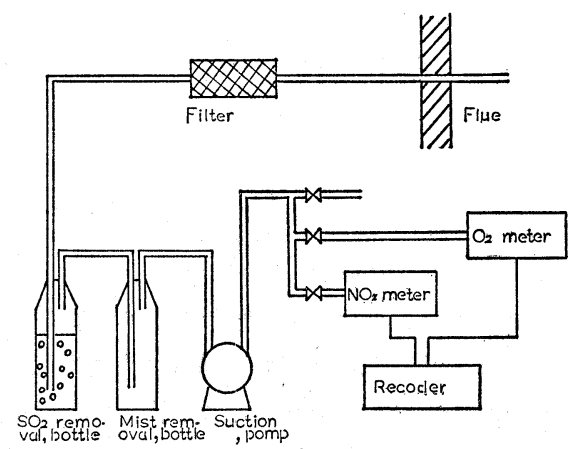

Fig. 1 Measuring apparatus

また，燃焼室内ガス温度は光高温計あるいは全放射 温度計を用いて測定を行なった。測定対象ボイラには 加圧然焼方式をとっているものもあり, また測定孔位 置などの関係もあって運転時に吸引温度計などを直接 挿入して温度計測を行ならことができないため, 簡便 な上記のような方法をとった。

\section{4. 測 定結果}

各ボイラの通常運転時における空気比と $\mathrm{NO}_{x}$ 量の 関係を Fig. 2 Fig. 9 に示す。図中の換算濃度とは, 容積 $\mathrm{ppm}$ で絶対值の比較が行なえるように測定濃度 を次式により空気比 1.0 での燃焼ガスの状態に引き直 したものである。

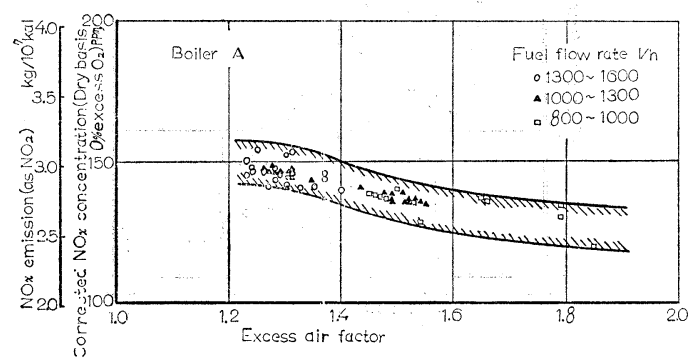

Fig. 2 Relation between $\mathrm{NO}_{x}$ emission and excess air factor (1)

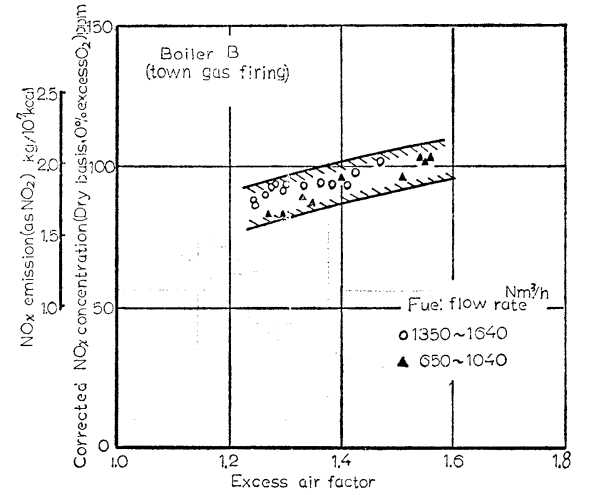

Fig. 3 Relation between $\mathrm{NO}_{x}$ emission and excess air factor (2)

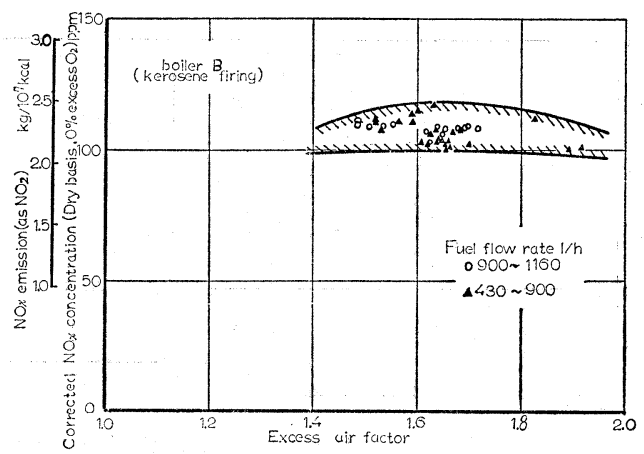

Fig. 4 Relation between $\mathrm{NO}_{x}$ emission and excess air factor (3)

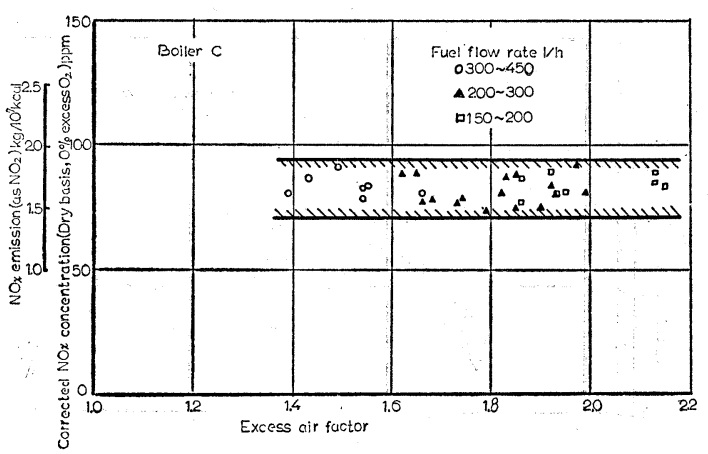

Fig. 5 Relation between $\mathrm{NO}_{x}$ emission and excess air factor (4) 


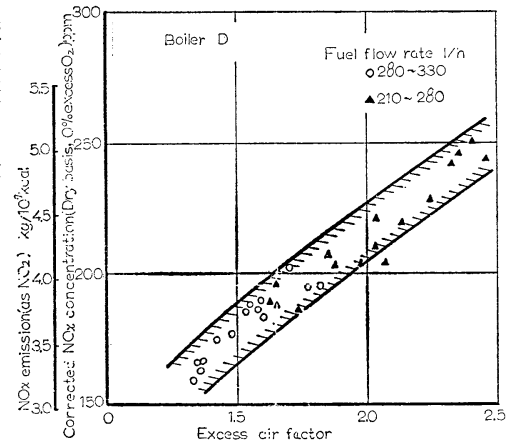

Fig. 6 Relation between $\mathrm{NO}_{x}$ emission and excess air factor (5)

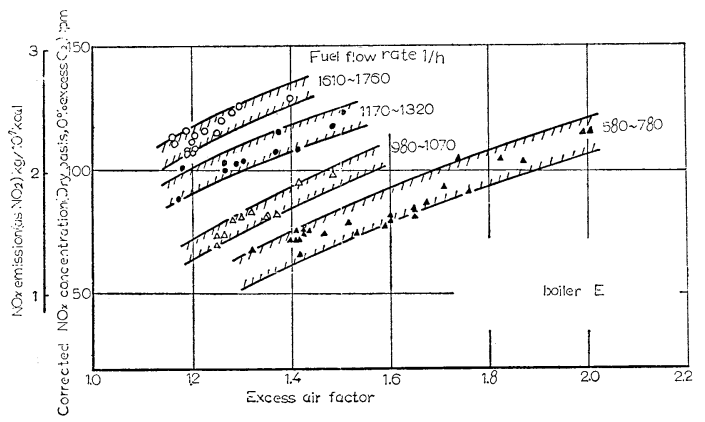

Fig. 7 Relation between $\mathrm{NO}_{x}$ emission and excess air factor (6)

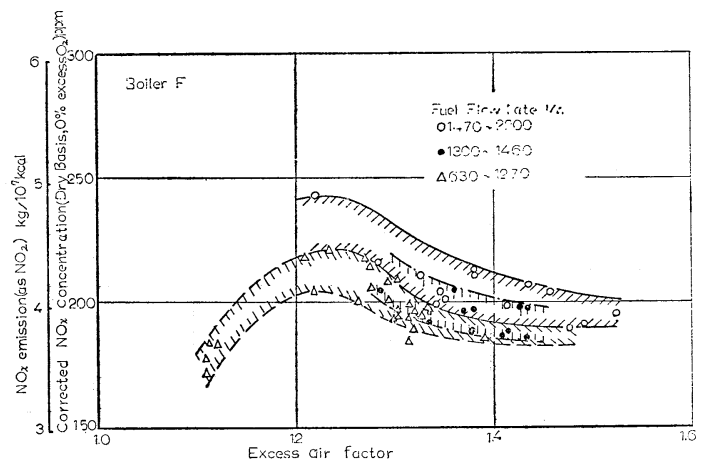

Fig. 8 Relation between $\mathrm{NO}_{x}$ emission and excess air factor (7)

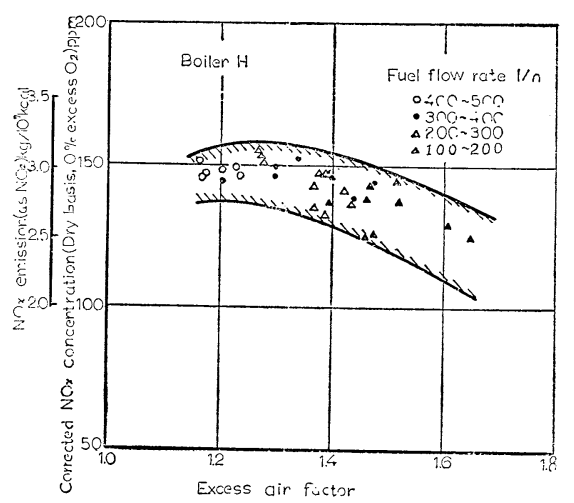

Fig. 9 Relation between $\mathrm{NO}_{x}$ emission and excess air factor (8)

$$
\left[\mathrm{NO}_{x}\right]_{c}=\frac{G^{\prime}}{G_{0}^{\prime}}\left[\mathrm{NO}_{x}\right]_{m}
$$

$\left[\mathrm{NO}_{x}\right]_{c}$; 換算 $\mathrm{NO}_{x}$ 濃度 $\mathrm{ppm}$ $\left[\mathrm{NO}_{x}\right]_{m}$; 測定 $\mathrm{NO}_{x}$ 濃度 $\mathrm{ppm}$

$G^{\prime} ; \mathrm{NO}_{x}$ 計測時の乾き燃焼ガス量 $\mathrm{Nm}^{3} / \mathrm{kgf}$ $G_{0}^{\prime}$; 理論乾き燃焼ガス量 $\mathrm{Nm}^{3} / \mathrm{kgf}$

また，使用燃料が異なる場合の比較には，発生熱量 当りの排出量を用いている。（液体および固体燃料に 対しては ton $f$ 当り, 気体然料に対しては $\mathrm{Nm}^{3} f$ 当 りで示す方法もとられるが，ここでは性能值も考慮し て比較が行なえるように発生熱量 $10^{7} \mathrm{kcal}$ 当りの排出 量で整理した。排出重量は $\mathrm{NO}_{x}$ をすべて $\mathrm{NO}_{2}$ であ るとして求めている。)

一般に, ボイラ燃焼においては, 制御系統の関係で

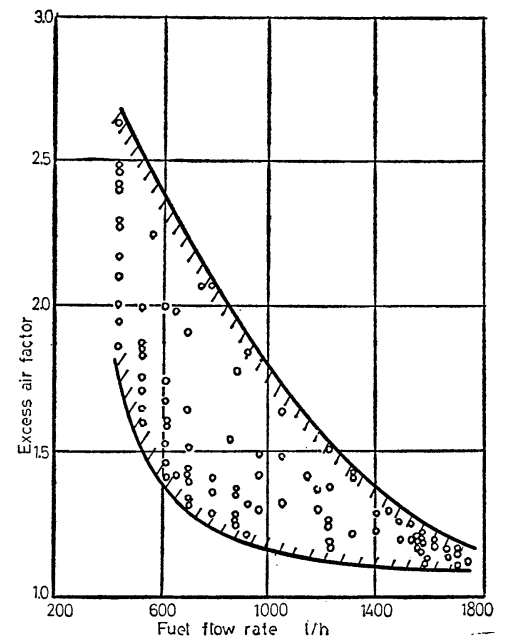

Fig. 10 Ane example of the relation between fuel flow rate and excess air factor (Boiler E) 
自動運転状態では Fig. 10 に示すように同一燃焼量に 対応する空気比はかなり広い幅をもっている。このよ うな燃焼量と空気比の関係があるため, $\mathrm{NO}_{x}$ 量と空 気比の関係においても区分した燃焼量範囲間で重なり 合う部分が生じる。

Fig. 11 Fig. 13 に定常運転時における空気比と $\mathrm{NO}_{x}$ 量の関係を示す。ボイラ Bにおいては, 都市ガ ス焚きと灯油焚きで蒸発量を一致させており, これに よって出力を同じにした場合の両者の比較を行ならこ とができる。またボイラBでは, 都市ガス焚き, 灯油 焚きのいずれにおいても火炎が青色透明になるので, 全放射温度計の計測結果を燃焼ガス温度の形で表示す ることはできない。そこで測定值は燃燒ガスと炉壁か らの放射熱量として示し, 火炎温度の傾向を見るにと どめた。放射熱量が大きければ然焼ガス温度も高いと 考えてよい。ただし, 全放射温度計のセットする位置 のわずかな “ずれ” や測定孔ガラス空の “よごれ”な どが測定值にかなり影響するので，この計測からは然 焼量一定の同一条件における傾向のみを見るだけに

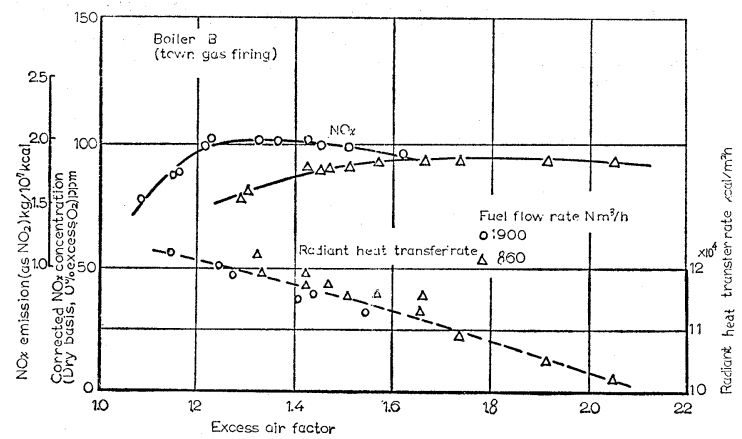

Fig. 11 Relation between $\mathrm{NO}_{x}$ emission and excess air factor (9) [Constant road]

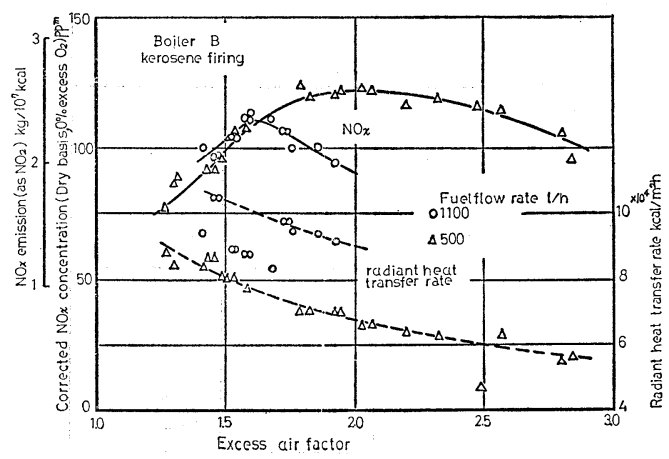

Fig. 12 Relation between $\mathrm{NO}_{x}$ emission and excess air factor (10) [Constant road]

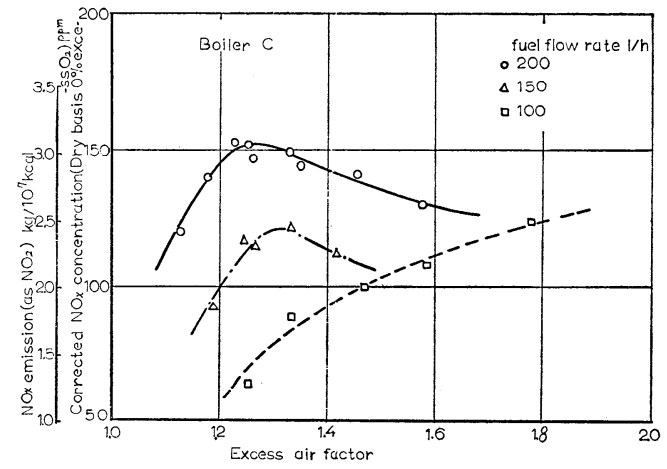

Fig. 13 Relation between $\mathrm{NO}_{x}$ emission and excess air factor (11) [Constant road]

し，使用燃料や燃焼量が違った場合についての比較は 行なわないことにする。

その他の重油焚きボイラでは, 光高温計により燃焼 室内ガス温度を測定した。

$$
\text { 5. 考 察 }
$$

$5 \cdot 1$ 空気比と $\mathrm{NO}_{x}$ 量

$\mathrm{NO}_{x}$ の発生が燃焼温度や燃焼域での $\mathrm{N}_{2}, \mathrm{O}_{2}$ 分圧 に影響されるため, 前にも述べたように空気比は, $\mathrm{NO}_{x}$ の排出量に関係する燃燒条件としては最も重要 な要素である。

これまでの, 空気比と $\mathrm{NO}_{x}$ 量の関係などで割合詳 細な結果が報告されている計測例は, 殆んどが発電用 の大形ボイラについて行なわれたものであるが，この 場合には今回測定のボイラEに見られるように，空気 比が高くなるほど, また燃焼量が増すほど $\mathrm{NO}_{x}$ 量が

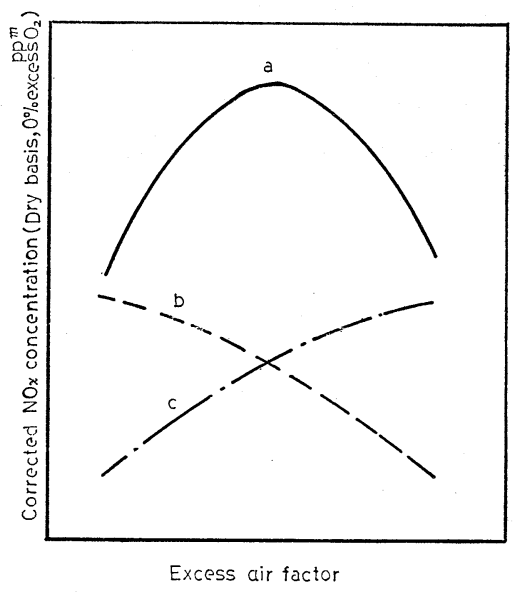

Fig. 14 Typical patterns in the relation between $\mathrm{NO}_{x}$ emission and Excess air factor 
増加する傾向を示すものが大部分である。しかし，今 回の測定結果の中には, 上記の傾向と逆の関係を示す ものなどもあり,これらを整理してみると, 空気比に 対する $\mathrm{NO}_{x}$ 量の関倸は $\mathrm{Fig} .14$ に示すような 3 つの パターンに分類することができる。

aに属するもの, B灯油焚き, C（このボイラでは フラットなパターンを示しているが，後述の運転空気 比の範囲と燃焼室内での燃料と空気の混合特性の関係 によって生じた a の特殊な場合であると考えることが できる。) $\mathrm{F}, \mathrm{H}$

bに属するもの一 $\mathrm{A}$

cに属するもの一- B 都市ガス焚き, $\mathrm{D}, \mathrm{E}$

測定対象ボイラがいずれのパターンを示すかは, 以 下に詳しく述べるように運転空気比の範囲と燃焼室内 での然料と空気の混合特性によって決まってくる。

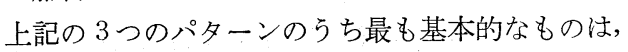

ある空気比の点で $\mathrm{NO}_{x}$ 量がピークを示すカーブ a で ある。 b と $\mathrm{c}$ は $\mathrm{a}$ カーブのピーク点の両側の曲線に相 当するものであり, 運転空気比の範囲が, そのボイラ が示すであろう a カーブのピーク点より大きい場合に はbになり，小さいときには $\mathrm{c}$ をとることになる。 あるいは c カーブを示すボイラでも, 運転空気比の範

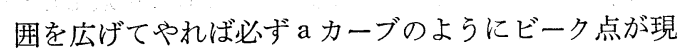
われるはずである。このことはボイラ Bにおける測定 結果からも確認される。すなわち, 通常運転では都市 ガス焚きの場合, cカーブを示しているが, 燃焼量一 定で空気比をかなり大幅に変化させた定常運転時には a カーブになっている。それではつぎに空気比と $\mathrm{NO}_{x}$ 量の関倸における基本形が a カーブであるという理由 について述べることにする。

燃焼において発生する $\mathrm{NO}_{x}$ はその生成経路から Thermal $\mathrm{NO}_{x}$ (空気中の窒素が高温において酸化され て生成するもの) と Fuel $\mathrm{NO}_{x}$ (燃料中の $\mathrm{N}$ 化合物 が燃燒に際して酸化されるもの) に分けられる。

ボイラ燃焼に扔ける Thermal $\mathrm{NO}_{x}$ の発生は, 平 衡論的な取り扱いによっては理解できず，速度論的な 考慮をはらわなければならないことはすでに報告した 通りである2334)。筆者らはこれまでの研究において,

$\mathrm{NO}\left(\mathrm{NO}_{2}\right.$ は $\mathrm{NO}$ の酸化によって生じると考えられ るので, 理論的な取り扱いにおいては NO の生成濃 度を $\mathrm{NO}_{x}$ 濃度と考えてよい) が見かけ上, $\mathrm{N}_{2}$ と $\mathrm{O}_{2}$ の 2 分子反応によって生成されるとし, その反応速度 定数 $k$ がアレニムウスの式に従うものとした場合, 活 性化エネルギーとして $37,000 \mathrm{kcal} / \mathrm{kmol}$ という值を 得た。

$$
\begin{aligned}
& \mathrm{N}_{2}+\mathrm{O}_{2} \stackrel{k}{\longrightarrow} 2 \mathrm{NO} \\
& k=f \cdot \exp (-E / R T)
\end{aligned}
$$

$f$; 頻度係数 $1 / \mathrm{ppms}$ (一般的には $\mathrm{cc} / \mathrm{mol} \cdot \mathrm{s}$ な どが使われるが，ここでは後述の式の関係で ppm の形で定義する。)

$F$; 活性化エネルギー $\mathrm{kcal} / \mathrm{kmol}$

$R$; 一般ガス定数 $\quad \mathrm{kcal} / \mathrm{kmol} \cdot{ }^{\circ} \mathrm{K}$

$T$; 反応温度 ${ }^{\circ} \mathrm{K}$

ボイラ内での燃焼状況を簡単化して, 最高燃焼温度 域において同一の滞留時間を持つものと考光, 反応速 度式を考慮すると $\mathrm{NO}_{x}$ 生成量は次式で表わすことが できる。

$$
\left[\mathrm{NO}_{x}\right]_{\mathrm{th}}=k\left[\mathrm{~N}_{2}\right]\left[\mathrm{O}_{2}\right] \tau_{r}
$$

$\left[\mathrm{NO}_{x}\right]_{\mathrm{th}}$; 理論的 $\mathrm{NO}_{x}$ 生成量 $\mathrm{ppm}$

$\left[\mathrm{N}_{2}\right],\left[\mathrm{O}_{2}\right]$; 燃焼温度における $\mathrm{N}_{2}, \mathrm{O}_{2}$ の平衡濃 度 $\mathrm{ppm}((2)$ 式との関係で, 単位を 合せるため ppm を用いている。)

$\tau_{r} ;$ 最高燃焼温度域における燃焼ガスの 滞留時間 $s$

いま, この式に前述の換算濃度の考え方を導入して 整理すると，

$$
\begin{aligned}
{\left[\mathrm{NO}_{x}\right]_{\mathrm{kin} .} } & =\frac{G^{\prime}}{G_{0}^{\prime}} \frac{\left[\mathrm{NO}_{x}\right]_{\mathrm{th}}}{f \cdot t_{r}} \\
& =\frac{G^{\prime}}{G_{0}^{\prime}}\left[\mathrm{N}_{2}\right]\left[\mathrm{O}_{2}\right] \exp (-E / R T)
\end{aligned}
$$

となる。 $f, t_{r}$ は定数であり, この式より空気比と速 度論的な換算 $\mathrm{NO}_{x}$ 濃度の関係が求まることになる。 Fig. 15 は, 燃料として重油あるいは灯油の組成に近

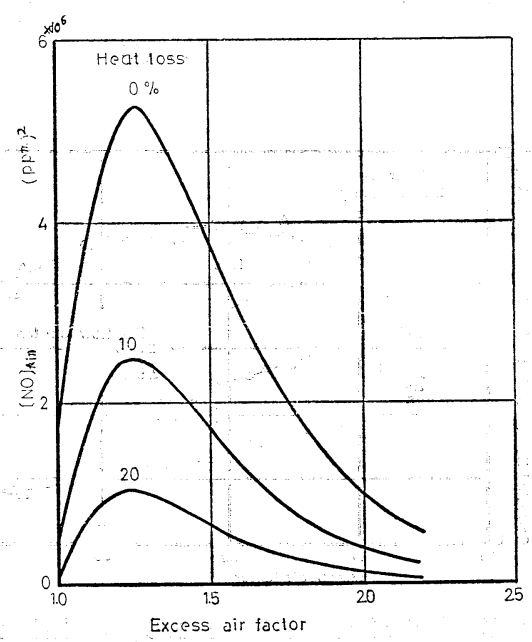

Fig. 15 Kinetic $\mathrm{NO}_{x}$ formation 
い, c ; 87.6\%，h；12.4\%を考え，熱損失 0,10 , $20 \%$ のきに対して空気比と $\left[\mathrm{NO}_{x}\right]_{\mathrm{kin}}$. の関係を示 したものである。この考察は非常に大ざっぱな仮定を 基にしたものではあるが，ボイラ燃焼においては，反 応速度論的に考えて Thermal $\mathrm{NO}_{x}$ の排出量がある 空気比の点でピークを持つということの説明には充分 である。ピーク点より低空気比側で $\mathrm{NO}_{x}$ 量が減少す るのは然焼域における $\mathrm{O}_{2}$ 濃度の低下のためであり, 一方, 高空気比側では燃焼温度の低下のため $\mathrm{NO}_{x}$ 発 生は減少する。この温度低下は, Fig. 11, Fig. 12 の 測定結果でも確認される。

しかし, この Thermal $\mathrm{NO}_{x}$ のピーク点の空気比 は, Fig. 15 に示されるように 1.2 付近に常に生じる とはかぎらない。それは同一の空気比で然焼させた場 合でも, ボイラによって燃焼方式が異なり, 燃焼室内 での燃料と空気の混合状態が変って燃焼域での空気比 に違いが生じるためである。いいかえれば, 燃焼室内 での混合の良否により燃焼室内に投入される空気量の らち燃焼に関与する割合が異なるためである。ピーク 点の空気比は燃焼室内での燃料と空気の混合が良好な ほど低空気比側に移ることになる。

このことに関して, 試験用ボイラ I の結果を用いて 若干の考察を加えることにする。ボイラI では灯油を 燃料としており, Fuel $\mathrm{NO}_{x}$ の生成はほとんどないも のと考えてよい。Fig. 16 は, ボイラIにおいて燃焼 量を 5 段階に変化させた場合の空気比と $\mathrm{NO}_{x}$ 量の関 係を示したものであるが，この図からわかるように $\mathrm{NO}_{x}$ 量の ピーク点は燃焼量が低下するほど高空気比 側に生じている。ボイラIにおいては燃焼量を変化さ せる場合, 燃焼量ごとにバーナチップを交換し, 油圧

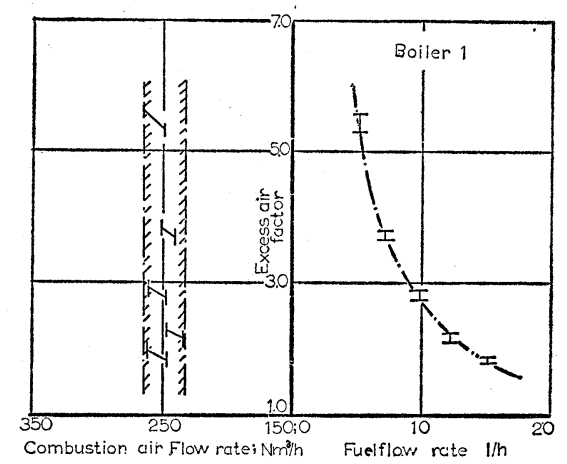

Fig. 17 Excess air factor and Combustion air flow rate at maximum $\mathrm{NO}_{x}$ emission
を一定に保ってできるだけ噴霧状況に変化がないよう にしている。このようにした場合, 燃焼室内での混合 特性については燃焼室内に入る空気側の流入条件が支 配的であると考えられる。そこで $\mathrm{NO}_{x}$ 量のピーク点 を空気量で整理したのが Fig. 17 である。この図から

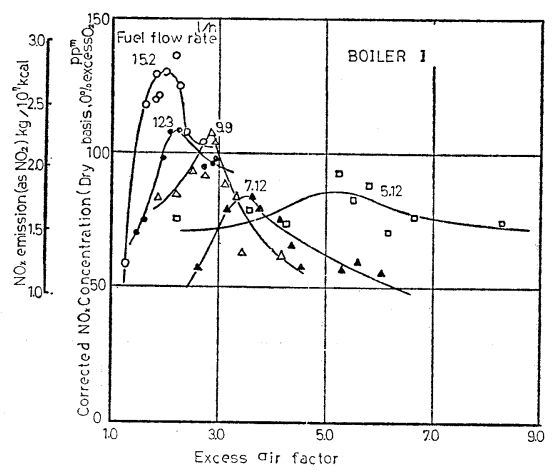

Fig. 16 Relation between $\mathrm{NO}_{x}$ emission and excess air factor (12) [Constant road]

わかるように, 燃焼量によってピーク点空気比は違っ ても, 空気流量で整理してみるとほぼ同一の範囲にあ ることがわかる。つまりほぼ同様な混合状態が得ら れるところで $\mathrm{NO}_{x}$ のピーク点が生じていることにな る。

ボイラBにおける定常運転の結果では然焼量が増大 するほど $\mathrm{NO}_{x}$ 量ピーク点の空気比は低くなっており, 上述のことから考えて高燃焼量で流入空気量が多い方 が混合状態が良いようである。

また，ボイラBにおける計測では通常運転の場合に は, 運転空気比の範囲が狭いため明瞭には現われてい ないが，定常運転では都市ガス焚きの方が灯油焚きよ り低空気比側に $\mathrm{NO}_{x}$ ピーク点が見られる。これはガ ス燃焼が，噴霧燃燒に比較して本質的に混合の良好化 をはかりやすいことによるものであると考えられる。

一方, Fuel $\mathrm{NO}_{x}$ については, 燃料中の $\mathrm{N}$ 化合物 からの $\mathrm{NO}_{x}$ への変換率が問題であるが， $\mathrm{N}$ 化合物 の種類にはよらないこと ${ }^{5) 6)}$, 空気比が増大するほど 変換率も上昇すること7), また噴霧燃焼の場合には $\mathrm{N}$ 分含有率7) も燃燒温度 ${ }^{8)}$ もままり影響しないことなど が知られている。しかし, 変換率の值は実験者により まちまちであり, 数\%から $70 \%$ の幅をもっている。

Fig. 18 は小形の燃焼装置において, 燃料であるト ルエンにキノリン $\left(\mathrm{C}_{9} \mathrm{H}_{7} \mathrm{~N}\right)$ を添加して行なった筆者 らの実験結果であるが，同図中に併記した瀬間らての 結果と比較すると空気比および然料中 $\mathrm{N}$ 含有率に対す 
る傾向は類似であるが，変換率の絶対值はかなり異な っている。この原因は燃焼域での $\mathrm{O}_{2}$ 濃度の差による ものと考えられ，つまりは燃料と空気の混合特性が強 い影響をもっていることになる。

このように Fuel $\mathrm{NO}_{x}$ の生成に対しても, 運転空 気比の範囲と燃焼室内での燃料と空気の混合特性は重 要な影響因子である。

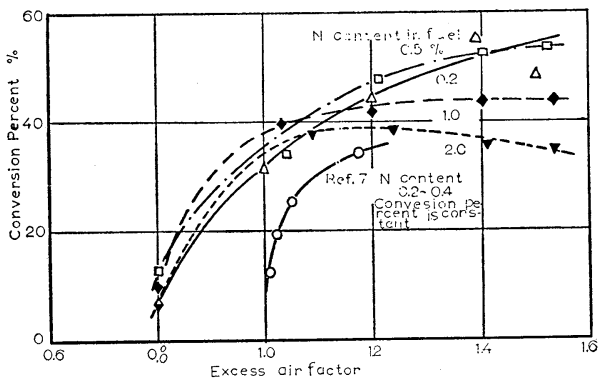

Fig. 18 Conversion $\mathrm{N}$ in fuel to $\mathrm{NO}_{x}$ as a function of excess air factor

しかし, Fuel $\mathrm{NO}_{x}$ は Fig. 18 にみられるようにある 濃度で飽和する傾向をもっているので, Thermal $\mathrm{NO}_{x}$ と Fuel $\mathrm{NO}_{x}$ の合計として表われる排出 $\mathrm{NO}_{x}$ 量は, 高空気比まで燃焼範囲 を広げれば低下することにな

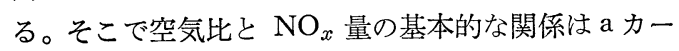
ブになる。

これまで述べてきた考察を基にして，ここで改めて 発電用の大形ボイラが Fig. 14 に示される c カーブを とる理由を考えてみる。大形ボイラでは多数のバーナ を数段に配置した燃焼室構造になっており, 同一容量 のバーナ相互間の干渉があって一般に燃焼室内での混 合状態は悪いと考えられる。このためピーク点空気比 は高空気比側に生じることになる。また, 運転空気比 も低過剩空気燃焼を行なっているため低く, 作動範囲 もかなり狭いため Thermal $\mathrm{NO}_{x}$ に対してはピーク 点にまでは到らず, Fuel $\mathrm{NO}_{x}$ については変換率の上 昇する部分に相当することになる。そこで大形ボイラ では空気比と $\mathrm{NO}_{x}$ 量の関係において $\mathrm{c}$ カーブを示す ことになる。

一般には, 同一ボイラにおいて燃焼量を増加させる と放熱量の割合が低下し，燃焼室内ガス温度が上昇す るため Thermal $\mathrm{NO}_{x}$ 量は増加すると考えられてい る。しかし，今回の通常運転時の計測では，この傾向 があまりはっきり認められないものが多い。定常運転 では, ボイラ Bの都市ガス焚きの場合のように燃焼量 が大なるほど $\mathrm{NO}_{x}$ 量も高くなるものもあるが，この
場合にも高空気比側ではこの関倸が逆転する傾向が見 られる。特にボイラ Bに扔ける灯油焚きではこの関係 は明らかである。また試験用ボイラIにおいてもピー ク点濃度は燃焼量の増加とともに高くなるが，それを はずれた空気比範囲では逆の関係を示しているところ がある。この原因は前にもふれた運転空気比の範囲と 燃燒室内での混合特性の影響によるものであって, ボ イラ燃焼における $\mathrm{NO}_{x}$ の発生には, 燃焼量の影響も それ単独では考えることができないことがわかる。 つまり混合状態や空気比の範囲によっては燃焼量と $\mathrm{NO}_{x}$ 量の関係が逆転することも充分起り得ることで ある。

$5 \cdot 2$ ボイラ容量と $\mathrm{NO}_{x}$ 量

一般に, ボイラ容量が大きくなるほど $\mathrm{NO}_{x}$ 量は増 大すると考えられている。これは大形化すると表面積/ 体積が減少し, 放熱量が低下して燃焼ガス温度が上昇 すると考えられるからである。しかし，今回の測定の 範囲内では $\mathrm{NO}_{x}$ 量に対しては, ボイラ容量よりむし ろ燃料の種類や燃焼条件の方が関連が強く, $\mathrm{NO}_{x}$ 量 とボイラ容量の間には明確な関係は認められない。

5.3 燃焼室内ガス温度と $\mathrm{NO}_{x}$ 量

Fig. 19 に重油燃焼ボイラにおける燃燒室内ガス温 度と $\mathrm{NO}_{x}$ 量の関係を示す。都市ガス焚きおよび灯油 焚きの場合には, 前述の理由により同図上で比較され る計測結果は得られていない。

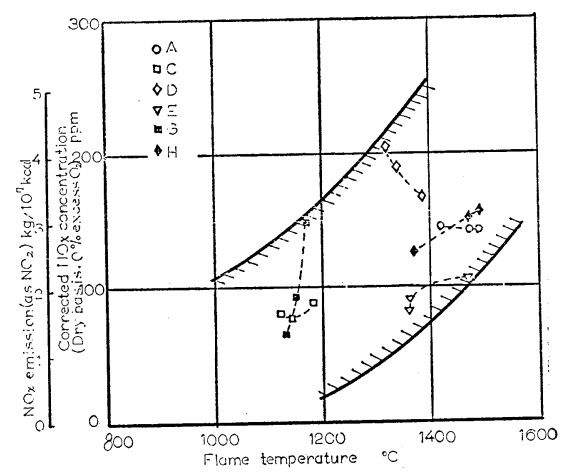

Fig. 19 Relation between $\mathrm{NO}_{x}$ emission and flame temperature

全体的には, 燃焼室内ガス温度と $\mathrm{NO}_{x}$ 量にはかな りの相関が認められ，燃焼室内ガス温度が高いほど $\mathrm{NO}_{x}$ 量も増加する傾向が見られる。しかし, 個々の ボイラについて見ると, ボイラDのようにこの関係が 逆になっているものも見られる。これは測定孔の位置 などの関係で限られた領域の燃焼ガスについてしか温 
度計測ができず，高温域の測定が行なわれないためで あろらと考えられる。

5.4 燃焼室熱負荷と $\mathrm{NO}_{x}$ 量

Fig. 20 に燃焼室熱負荷と $\mathrm{NO}_{x}$ 量の関係を示す。 燃焼室熱負荷が大きくなると放熱量の割合が低下し，

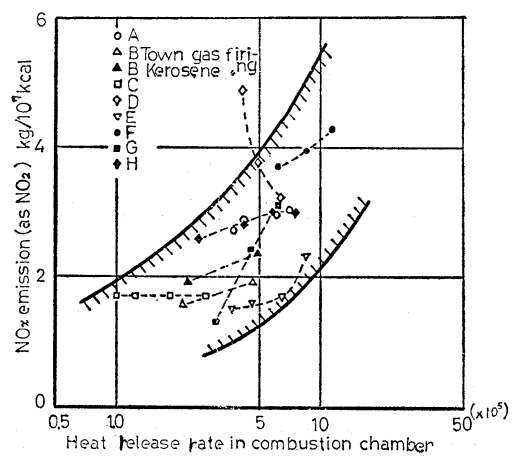

Fig. 20 Relation between $\mathrm{NO}_{x}$ emission and heat release rate in combustion chamber

燃焼室内ガス温度が 上昇すると考えられるので $\mathrm{NO}_{x}$ 量は増加する。同一ボイラにおいては, 燃焼量（熱負 荷) と $\mathrm{NO}_{x}$ 量の関係が必ずしも一定でないことは前 にふれたが，ボイラについて統一的に整理するにはや はり燃焼室熱負荷による方法が適当であろう。

これまでのボイラは, コンパクト化のため, より高 負荷然焼を行おうとする傾向が強かった。この方向 は, $\mathrm{NO}_{x}$ に関しては発生量を増大させることにつな がり, 今後この点について何らかの配慮が必要になっ てくるであろう。

\section{5 使用燃料と $\mathrm{NO}_{x}$ 量}

\section{5 .1 燃料の種類と $\mathrm{NO}_{x}$ 量}

今回測定したボイラのうち, A と B は若干容量が異 なるが形式が同じであり， A は重油， B は都市ガスと 灯油を使用然料としているので, これらのデータを用 いて燃料の種類と $\mathrm{NO}_{x}$ 量の関係について考えてみる ことにする (灯油と重油の 比較は 次節で考慮する)。 計測時の運転状況を見ると燃焼室熱負荷 $H_{r}$ にも重な り合う領域があり，充分比較の資料として採用できる ものであると考えられる。Fig. 21 に通常運転時の燃 料の種類と $\mathrm{NO}_{x}$ 排出量の関係を示す。使用燃料が違 う場合つ比較には, 発生熱量当りの排出量を用いるの が適当である。

Fig. 21 よりわかるように, 重油, 灯油, 都市ガス の順に $\mathrm{NO}_{x}$ 排出量は減少する。都市ガス焚きと灯油 あるいは重油焚きの $\mathrm{NO}_{x}$ 発生に及ぼす影響のうち,

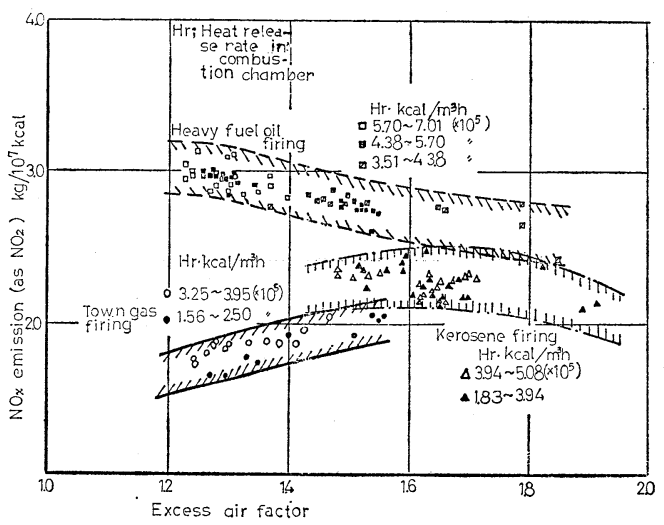

Fig. 21 Influence of fuel type on No emission

かなりの部分がガス燃焼と油滴燃焼の差違によってい るものと考えられる。灯油や重油焚きの場合のような 噴霧油滴燃焼では, 全体としてはかなり空気過剩の燃 焼を行なっている場合でも, 油滴自体はその外周に形 成される拡散炎においてほぼ空気比 1.0 の状態で然え ているものと考えられる。このような場合には, 高温 の燃焼域が長くなり, $\mathrm{NO}_{x}$ 発生量は増加する。しか し, 噴霧燃燒においても全燃料が全然焼域にわたって 以上のような燃焼形態をとるわけではなく, 微小油滴 は霧化された直後に, またかなり大きな油滴も火炎の 後部ではガス燃焼に近い状態で然えていることは留意 しておかねばならない。一方, ガス燃焼ではバーナ形 式などから考えて噴霧燃焼より本質的に混合の良好化 がわかりやすい。そこで然焼域の空気比も全体の空気 比と同程度にすることができるため, 燃焼温度は低下 し, さらに燃燒域も短かくなるので $\mathrm{NO}_{x}$ 発生量は減 少すると考元れる。

燃料の種類と $\mathrm{NO}_{x}$ 量の関係については, 燃焼室内 での混合特性もかなり強い影響を及ぼすので, ガス焚 きから重油焚きに変えたところ $\mathrm{NO}_{x}$ が $1 / 2$ 以下にな った ${ }^{9)}$ といらことも充分起りらることであるが，一般 的には使用燃料の燃燒方式から考えて今回の計測例の ごとき結果を示す場合が多いものと思われる。

$5 \cdot 5 \cdot 2$ 液体然料での $\mathrm{NO}_{x}$ 排出量の差

液体燃料を使用する場合には, 粗悪な燃料では $\mathrm{N}$ 分 含有率が高く, Fuel $\mathrm{NO}_{x}$ が堌加するため $\mathrm{NO}_{x}$ 排出 量は増加する傾向がある。Fig. 22 は本計測後に行な った燃料性状調查 ${ }^{100}$ にって得られた燃料中の $\mathrm{S}$ 分と N分の関係を示したものである。電力用ボイラで使用 されている低 $\mathrm{S}$ 分のミナス原, 重油を除くと $\mathrm{S}$ 分と $\mathrm{N}$ 分の間にはほぼ直線関係が見とめられる。この関係か 
ら類推してN分含有率を求めたのが Table 2 に示す 值である（ただし，ボイラAおよびGで使用している 重油は特 $\mathrm{A}$ 重油と呼ばれるミナス系の低 $\mathrm{S}$ 分のもので あるので電力用と同程度の $\mathrm{N}$ 分が含まれているものと 考えた)。

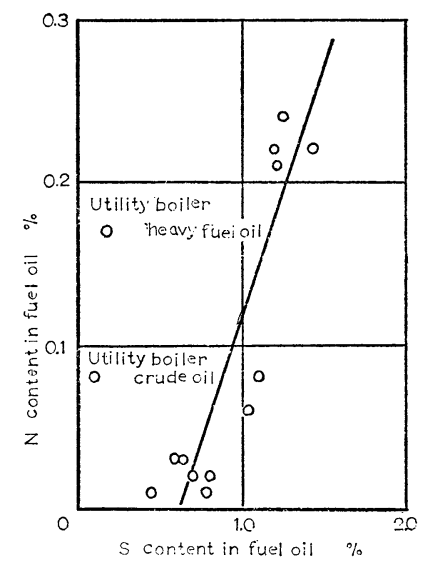

Fig. 22 Relation between $N$ and $S$ content in fuel oil

Fig. 23 はこのように推定した $\mathrm{N}$ 分と $\mathrm{NO}_{x}$ 量の関 係を示したものである。重油の場合， $0.1 \%$ の $\mathrm{N}$ 分が すべて $\mathrm{NO}_{x}$ に変化したとすると換算濃度で約 155 ppm の $\mathrm{NO}_{x}$ 濃度を示すことになるので, Fig. 23 か らは約 $39 \%$ の変換率をもつことがわかる。

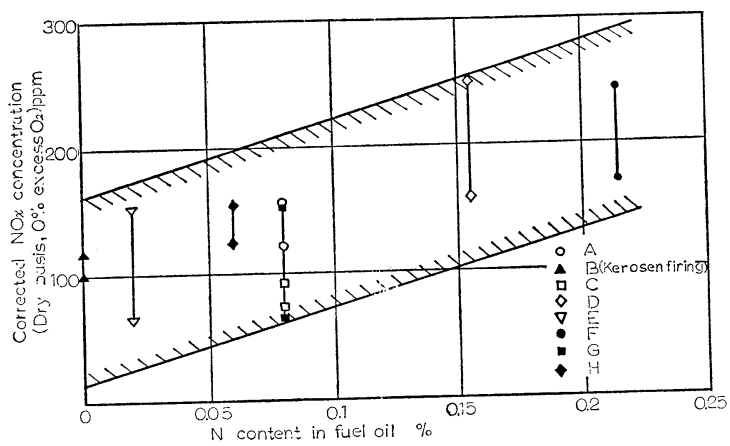

Fig. 23 Influence of $\mathbf{N}$ content in fuel oil on NO ${ }_{x}$ emission

なおっここでは $\mathrm{N}$ 分以外の影響因子は考慮していな いが， N分の多い粗悪な燃料は粘度も高く, 噴霧粒径 が大きくなるので油滴の然え切り時間も長く, それに よる Thermal $\mathrm{NO}_{x}$ の増加も考えられる。しかし, その影響についてはほとんどわかっておらず，現在筆 者らは研究を行なっているところである。
6. ま と め

暖冷房用あるいは工場用蒸気源として使用されてい る中小形ボイラについて， $\mathrm{NO}_{x}$ 排出量と燃焼条件と の関連を調べた結果，つぎのような結論を得た。

1) 蒸発量 5 26t/h までのボイラについて計測を 行なったが, 発生熱量当りの $\mathrm{NO}_{x}$ 排出量は $1 \sim 5 \mathrm{~kg} /$ $10^{7} \mathrm{kcal}$ であった。

2) $\mathrm{NO}_{x}$ 排出量に対してボイラ 容量はほとんど関 係しない。

3）燃焼室内ガス温度と $\mathrm{NO}_{x}$ 排出量にはかなりの 相関が認められ，燃焼温度が高いほど $\mathrm{NO}_{x}$ 量も多く なる。

4）また, 燃焼室熱負荷に対しても同様の傾向が認 められる。

5) ボイラに扔ける空気比と $\mathrm{NO}_{x}$ 排出量の関倸は 3 つのパターンに分類でき, 測定対象ボイラがどのパ ターンをとるかは運転空気比の範囲と燃焼室内での燃 料と空気の混合特性によって決まる。

6）使用然料によっても $\mathrm{NO}_{x}$ 排出量は変わり, 重 油, 灯油, 都市ガスの順に $\mathrm{NO}_{x}$ 量は低下寸る。特に 液体燃料ではN分の高い燃料ほど Fuel $\mathrm{NO}_{x}$ が増加 するため排出量が多くなる。燃料中の $\mathrm{N}$ 分からの $\mathrm{NO}_{x}$ の変化率は約 $39 \%$ であた。

燃焼技術による $\mathrm{NO}_{x}$ 抑制対策としては, 現在, 低 過㮃空気燃燒, 二段燃焼, 排ガス循環燃焼, 排ガス循 環二段燃燒, 蒸気あるいは水噴射, Off stoicheometric combustion，バーナおよびェアレジスタ の改良など の方法が考えられている。このらち低過剩空気燃燒は 運転空気比を変更するだけなので最も応用しやすい $\mathrm{NO}_{x}$ 低減法であると考えられているが，今回の調查 で示したように, 空気比と $\mathrm{NO}_{x}$ 量の関倸は一義的な ものでなく, 現行よりも低空気比での燃焼が $\mathrm{NO}_{x}$ 量 の増加をまねく場合もあることは留意しておかねばな らない。低過剩空気燃焼は，Fig. 14 の c カーブのよ うな空気比と $\mathrm{NO}_{x}$ 量の関係を示すものに対しては充 分効果があるが， bカーブの場合には，より低空気比 での燃焼では $\mathrm{HC}$ や $\mathrm{CO}$ 発生が心配されることもあ るので, $\mathrm{NO}_{x}$ 低減には高空気比側に運転範囲を移し た方が良いこともあろら。

バーナやエアレジスタ の改良あるいは再調整など による混合特性の改善む割合簡単に実行できそうな $\mathrm{NO}_{x}$ 低減対策である。しかし，混合特性の改善と $\mathrm{NO}_{x}$ の低減はこれまでにも示したように，運転空気 比ともからんではなはだ微妙であり, 充分な実験と調 查が必要である。 
今回の調査では測定数も少なく, ボイラの燃焼条件 と $\mathrm{NO}_{x}$ 排出量の関係についてほんの概略を知ったに すぎない。今後, さらに多くのボイラについての計測 が必要なことはいらまでもないことである。

おわりに本研究に際し，終始ご指導をたまわった小 泉睦男早大教授に心から感謝する次第です。また測定 に便宜をはかって下さった東京都公害局の方々, 関係 各会社の各位に深く謝意を表します。

\section{文献}

1) 永田他 3 名, 日本機械学会第 823 回講演会講演論 文集 (1972) 189

2) 永田, 日本機械学会誌, 75, 643, 1273 (1972)

3）永田, 望月, 然料協会誌, 52, 558, 778 (1973)

4) 永田, 望月, 同上, 52, 558, 785 (1973)

5) G. B. Martin and E. E. Berkau, An Investigation of conversion of various fuel nitrogen com- paunds to nitrogen oxides in oil combustion, AICHE National Meeting (1971)

6) D. W. Turner et al., Influence of combustion modification and fuel nitrogen content on nitrogen oxides emission from fuel oil combustion, Esso Research and Engineering Company Report (1971)

7) 瀬間他 2 名, 燃料中の窒素分が窒素酸化物生成に 及ぼす影響, 電力中央研究所技術第一研究所報告

8) N. V. Hakala et al., Control of $\mathrm{NO}_{x}$ emission from stationary combustion, ISAP 72 Tokyo (1972)

9) NEW, Control techniques for nitrogen oxides from stationary sources (1970)

10）小泉, 永田, 大気污染物質排出状況 (固定発生源) 調査結果報告書, 東京都公害局 (1973)

\title{
Influence of Burning Condition on NO $x$ Emission from Boilers
}

\author{
by Katsuya Nagata, Yuji Honma, Mikio Hirota \\ \& Kunihiro Matsubara \\ (Waseda University)
}

SYNOPSIS : - In this paper, $\mathrm{NO}_{x}$ emission from the $5 \sim 26 \mathrm{t} / \mathrm{h}$ boilers which are used for the air conditioning or steam source in factory and influence of burning condition on $\mathrm{NO}_{x}$ formation are researched.

The main results are summarized as follows.

1) $\mathrm{NO}_{x}$ emission from such boilers is $1 \sim 5 \mathrm{~kg} / 10^{7} \mathrm{kcal}$.

2) Boiler capacity doecs not influenced on $\mathrm{NO}_{x}$ emission.

3) $\mathrm{NO}_{x}$ emission highly depends on flame temperature. As temperature in higher, $\mathrm{NO}_{x}$ emission more increases.

4) Heat release rate in combustion chamber has same relation.

5) $\mathrm{NO}_{x}$-Excess air factor relation is divided into three patterns. The pattern that the tested boiler indicated, is determined by the range of excess air factor and fuel-air mixing in combustion chamber.

6) The type of fuel has an effect on $\mathrm{NO}_{x}$ emission. $\mathrm{NO}_{x}$ emission increases in the order of town gas, kerosene and heary fuel oil. On the boilers firing high $\mathrm{N}$ content fuel oil, $\mathrm{NO}_{x}$ emission increases. Fraction of $\mathrm{N}$ content converted to $\mathrm{NO}_{x}$ is $39 \%$. 